\title{
AMPA Receptor Activation Is Rapidly Toxic to Cortical Astrocytes when Desensitization Is Blocked
}

\author{
Jeannie C. David,' Kelvin A. Yamada, ${ }^{1,2}$ Mahesh R. Bagwe, ${ }^{1}$ and Mark P. Goldberg ${ }^{1,3}$ \\ Center for the Study of Nervous System Injury and Departments of ${ }^{1}$ Neurology, ${ }^{2}$ Pediatrics, and ${ }^{3}$ Anatomy and \\ Neurobiology, Washington University School of Medicine, St. Louis, Missouri 63110
}

Although cultured astrocytes express functional glutamate receptors, they are generally resistant to excitotoxic cell death. We explored the role of receptor desensitization in glutamatemediated astrocyte injury. In cultures of type 1 astrocytes from mouse neocortex, brief application of AMPA evoked small, rapidly desensitizing inward currents, whereas kainate evoked small, sustained currents. Neither agonist increased cytosolic calcium, and astrocyte toxicity occurred only after $24 \mathrm{hr}$ exposure to high $(500-1000 \mu \mathrm{m})$ concentrations of kainate but not to AMPA or glutamate.

Cyclothiazide, a drug that selectively blocks AMPA receptor desensitization, greatly potentiated AMPA- or kainate-gated currents and intracellular calcium elevation. Coapplication of 10-100 $\mu \mathrm{M}$ cyclothiazide with glutamate, AMPA, or kainate produced widespread astrocyte cell death within $2 \mathrm{hr}$ of application. The enhancement of toxicity by cyclothiazide, which alone was not toxic, was concentration-dependent for each of the tested agonists $\left(\mathrm{EC}_{50} 30-100 \mu \mathrm{M}\right)$ and was blocked by further addition of the selective AMPA/kainate antagonist 2,3dioxo-6-nitro-7-sulfamoylbenzo(f)quinoxaline (NBQX). NMDA caused no injury even in the presence of cyclothiazide. Cyclothiazide-enhanced injury varied with the age of astrocyte cultures; the maximal effect occurred at $\sim 2$ weeks in vitro, and little death was seen after 4 weeks. Type 1 astrocytes express AMPA-type glutamate receptors that are unmasked by reducing their desensitization with cyclothiazide. Although overactivation of AMPA receptors can be rapidly lethal to astrocytes, rapid desensitization normally limits this toxicity. The extent of AMPA receptor desensitization may be an important determinant of glial vulnerability to excitotoxic insults.

Key words: astrocytes; glutamate; glutamate receptors; desensitization; cell death; calcium; Fura-2; electrophysiology; cyclothiazide; cell culture
Cell death produced by excessive glutamate receptor activation, or excitotoxicity, is an important mechanism of neuronal injury associated with cerebral hypoxia-ischemia and other acute brain insults. It is not known whether similar mechanisms can also contribute to glial cell death in this setting. Glial cells express various membrane channels and ligand-gated receptors, including those for glutamate (see Barres, 1991; Hosli and Hosli, 1993). In vitro models of excitotoxic injury have consistently demonstrated a rapidly triggered neuronal cell death caused by glutamate activation of NMDA receptors and a more slowly developing excitotoxicity mediated by non-NMDA $[R, S \alpha$-amino-3hydroxy-5-methylisoxazole-4-propionic acid/kainate (AMPA/ kainate)] receptors (Choi, 1992). Although astrocytes do not express NMDA receptors (Kettenmann and Schachner, 1985) and would not be expected to be vulnerable to rapidly triggered NMDA toxicity, they do have functional non-NMDA ionotropic receptors. Therefore, it is interesting that direct ionotropic glutamate receptor activation is not toxic to cultured astrocytes. For example, in primary hippocampal or cortical cultures, glia survive exposures to glutamate, NMDA, or AMPA at concentrations sufficient to destroy almost all neurons (Rothman, 1984; Choi et al., 1987; Koh et al., 1990).

\footnotetext{
Received Aug. 11, 1995; revised Oct. 4, 1995; accepted Oct. 6, 1995.

This work was supported by NIH Grants NS32636 (M.P.G., K.A.Y.), NS01543 (M.P.G.), and NS01443 (K.A.Y.). We thank Angie M. Rosengarten and Krzysztof Hyrc for performing calcium measurements.

Correspondence should be addressed to Mark P. Goldberg, Department of Neurology, Box 8111, Washington University School of Medicine, 660 South Euclid Ave., St. Louis, MO 63110.

Copyright $(1995$ Society for Neuroscience $0270-6474 / 95 / 160200-10 \$ 05.00 / 0$
}

Several explanations may account for the relative resistance of cultured astrocytes to glutamate-mediated toxicity. Astrocytes may express few glutamate receptors, their glutamate receptors may be functionally different from neuronal glutamate receptors, or they may lack the intracellular processes that are operative in neurons to link glutamate receptor activation to cell death. We have explored the hypothesis that glutamate receptor desensitization influences glial vulnerability. Non-NMDA receptor-linked channels are characterized by desensitization despite the continued presence of agonist (Zorumski and Thio, 1992), and receptor subtypes can be distinguished by the rate and pharmacology of this desensitization. AMPA receptors exhibit rapidly desensitizing currents with AMPA application and more sustained currents with kainate application. The currents produced by both agonists are markedly potentiated by drugs such as cyclothiazide, which blocks AMPA receptor desensitization (Yamada and Tang, 1993; Patncau ct al., 1993). In contrast, kainate receptors exhibit descnsitizing currents with kainate agonists (Huettner, 1990), but their desensitization is unaffected by cyclothiazide (Wong and Mayer, 1993). Reducing desensitization with plant lectins or thiazides enhances AMPA/kainate-mediated excitotoxicity in cultured neurons (Zorumski et al., 1990; May and Robison, 1993; Moudy et al., 1994) and potentiates neuronal injury after deprivation of oxygen and glucose in cortical cultures (Probert and Marcoux, 1993; Bateman et al., 1993).

The physiological, molecular, and pharmacological characterization of glial non-NMDA glutamate receptors is less complete. Cyclothiazide potentiates whole-cell currents evoked by AMPA in glial cells of O-2A lineage (Patneau et al., 1994; Holzwarth et al., 
1994), which includes type 2 astrocytes and oligodendroglia (Raff et al., 1983). However, the effects of cyclothiazide on type 1 astrocyte AMPA- or kainate-evoked responses have not been described. The goal of the present studies was to assess a potential role of AMPA receptor desensitization in limiting excitotoxic injury to cultured type 1-like astrocytes derived from fetal mouse neocortex.

Preliminary reports have appeared in abstract form (David et al., 1995a,b).

\section{MATERIALS AND METHODS}

Cell culture. Cortical astrocyte cultures were prepared from neonatal Swiss-Webster mice (1-3 d postnatal) as previously described (Rose et al., 1993; Goldberg and Choi, 1993). Dissociated astrocytes were plated in media containing $10 \%$ equine serum, $10 \%$ fetal bovine serum, and epidermal growth factor $(10 \mathrm{ng} / \mathrm{ml})$ at a density of 0.05 hemispheres $/ \mathrm{ml}$ into 24 well multiwell plates (Primaria, Falcon, Bedford, MA) or at 0.2 hemispheres/ml into $35 \mathrm{~mm}$ dishes with glass coverslip bottoms (MatTek, Ashland, MA) coated with poly-D-lysine (Sigmia, St. Louis, MO) and laminin (Collaborative Research, Bedford, MA). Cultures were maintained in a $5 \% \mathrm{CO}_{2}$-humidified incubator at $37^{\circ} \mathrm{C}$.

Immunocytochemistry. Astrocyte cultures were fixed in $4 \% p$-formaldehyde in PBS, permeabilized as needed for $10 \mathrm{~min}$ in $0.25 \%$ Triton X-100, and then incubated for $1 \mathrm{hr}$ in $10 \%$ normal goat serum (NGS). Cultures were incubated at room temperature for $2 \mathrm{hr}$ with one of the following antibodies in PBS containing 2\% NGS: rabbit polyclonal antibody to glial fibrillary acidic protein (GFAP; 1:1 as supplied; Incstar, Stillwater, MN), mouse monoclonal antibody to the A2B5 antigen (not permeabilized, 1:100; Boehringer Mannheim, Indianapolis, IN), mouse monoclonal antibody to galactocerebroside (not permeabilized, 1:20; Boehringer Mannheim), or mouse monoclonal antibody to the microtubule-associated protein (MAP-2; 1:400; Boehringer Mannheim). After washing, cultures were exposed for $1 \mathrm{hr}$ to the appropriate guat Cy3-conjugated secondary antibody (1:100; Jackson Immunoresearch, West Grove, PA) at room temperature for $30 \mathrm{~min}$. Cells were examined under epifluorescence illumination on a Nikon Diaphot inverted microscope.

Electrophysiology. Established glial cell cultures 14-16 d in vitro were resuspended in growth medium and plated at low density onto $35 \mathrm{~mm}$ plastic dishes. Whole-cell recordings were performed on single cells 2-6 $\mathrm{hr}$ after replating at room temperature on the stage of an inverted microscope. Growth medium was replaced by an external recording solution that contained $140 \mathrm{~mm} \mathrm{NaCl}, 3.0 \mathrm{mM} \mathrm{KCl}, 1.0 \mathrm{mM} \mathrm{MgCl}_{2}, 2.0 \mathrm{mM}$ $\mathrm{CaCl}_{2}, 10 \mathrm{~mm}$ HEPES, and $10 \mathrm{mg} / \mathrm{l}$ phenol red, $\mathrm{pH}$ 7.3. The internal recording solution contained $130 \mathrm{mM} \mathrm{CsCl}, 10 \mathrm{mM} \mathrm{TEACl}, 10 \mathrm{~mm}$ HEPES, $1.1 \mathrm{mM}$ EGTA, and $5.5 \mathrm{~mm}$ glucose, $\mathrm{pH}$ 7.2. AMPA and kainate were dissolved directly into the external recording solution or were made from aqueous stock solutions. Stock solutions of cyclothiazide were prepared in dimethyl sulfoxide (DMSO) and diluted in recording buffer; the final DMSO concentration was $0.1 \%$ by volume. Patch electrodes were pulled in three stages (Sutter Instruments, Novato, CA) and had DC resistances of 5-10 M $\Omega$. These electrodes were connected to a patch amplifier in voltage-clamp mode using the whole-cell configuration (Hamill et al., 1981). Approximately $60-80 \%$ of the series resistance was compensated for. The holding potential was $-60 \mathrm{mV}$, unless indicated otherwise.

Continuous perfusion of the dish with drug-free recording solution was accomplished via gravity flow at a rate of $2-3 \mathrm{ml} / \mathrm{min}$. The recorded cell was also locally perfused via a large-borc fuscd silica-quartz tubc (internal diameter $320 \mu \mathrm{m}$ ) connected to four separate reservoirs, each with a separate solenoid valve to control its flow. Only one of the four valves could be opened at a time. AMPA or kainate was applied via a second flow tube, also connected individually to four separate reservoirs. Agonist was applied by simultaneously switching off the local wash reservoir and opening the agonist reservoir. Flow occurred via gravity. Steady-state currents were used for comparison and were defined as the averaged current during a $30 \mathrm{msec}$ interval at the end of the $300 \mathrm{msec}$ agonist application.

Measurement of cytosolic calcium. Astrocyte cultures were loaded with the acetoxymethyl ester of the cytosolic calcium indicator $4 \mu \mathrm{M}$ Fura-2 (Grynkiewicz et al., 1985) in a HEPES-buffered salt solution containing $116 \mathrm{~mm} \mathrm{NaCl}, 5.4 \mathrm{~mm} \mathrm{KCl}, 0.8 \mathrm{~mm} \mathrm{MgSO}_{4}, 1.01 \mathrm{mM} \mathrm{NaH}_{2} \mathrm{PO}_{4}, 25 \mathrm{~mm}$ $\mathrm{NaHCO}_{3}, 12 \mathrm{mM}$ IIEPES, $5.5 \mathrm{mM}$ D-glucose, $1.8 \mathrm{mM} \mathrm{CaCl}$, and $10 \mathrm{mg} / \mathrm{l}$ phenol red, $\mathrm{pH} 7.4$, for $30 \mathrm{~min}$ at room temperature and were incubated after washing for an additional $30 \mathrm{~min}$ to allow intracellular conversion to free Fura-2. Cultures were then placed on the stage of a Nikon Diaphot inverted microscope. Cells were examined under epifluorescence illumination using a $75 \mathrm{~W}$ xenon source, computer-controlled shutter and alternating $340 \pm 10$ and $380 \pm 10 \mathrm{~nm}$ excitation filters, $400 \mathrm{~nm}$ dichroic mirror, $510 \mathrm{~nm}$ emission filter, and a $40 \times$ oil-immersion objective (NA 1.3, Nikon). The emitted images obtained at 5-45 sec intervals were acquired with an intensitied charge-coupled device low-light camera (Hamamatsu Photonics, Oak Brook, IL) and digitized using an imageprocessing system (MetaFluor, Universal Imaging, West Chester, PA). Regions of interest were selected from phase-contrast videomicrographs before the experimental treatment, and $340 / 380 \mathrm{~nm}$ excitation ratios [proportional to cytosolic calcium concentration $\left.\left(\left[\mathrm{Ca}^{2+}\right]_{i}\right)\right]$ were calculated after background subtraction for each region. Experimental compounds were delivered by bath perfusion. $\left[\mathrm{Ca}^{2+}\right]_{i}$ values were calibrated by comparison with low and high calcium solutions (Grynkiewicz et al., 1985 ) containing $50 \mu \mathrm{M}$ free Fura- 2 and imaged in glass microslides with $20 \mu \mathrm{m}$ pathlength (Vitro Dynamics, Rockaway, NY).

Excitatory amino acid exposure. Astrocyte cultures were rinsed with serum-free Minimal Essential Medium (Gibco, Grand Island, NY) (modified by the addition of glucose, total $25.5 \mathrm{~mm}$, and the omission of glutamine) containing the experimental reagents and were incubated for $22-26 \mathrm{hr}$ in a $5 \% \mathrm{CO}_{2}$-humidified incubator at $37^{\circ} \mathrm{C}$. Cell damage was assessed by observation at $200-400 \times$ with phase-contrast optics. Loss of astrocyte viability was confirmed by incubating cultures with the fluorescent dye propidium iodide at $1 \mu \mathrm{g} / \mathrm{ml}$ for $10-20 \mathrm{~min}$ and by examining cultures under green epifluorescence. Videomicroscope images were acquired under phase-contrast or epifluorescence optics using a siliconintensified target camera (Hamamatsu) and were digitized using a PCbased image analysis system (MetaMorph, Universal Imaging, Boston, MA).

Cell death was assessed quantitatively by measurement of lactate dehydrogenase (LDH) released to the exposure medium $20-28 \mathrm{hr}$ after the beginning of agonist exposure (Koh and Choi, 1987). Values were expressed relative to $\mathrm{LDH}$ measurements from sister cultures maximally destroyed by $1 \mathrm{hr}$ exposure to the calcium ionophore, $10 \mu \mathrm{M}$ ionomycin $(=100)$, after subtraction of the small amount of $\mathrm{LDH}$ present in control cultures exposed only to wash conditions $(=0)$. Each experiment was performed on sister cultures of a single plating and was representative of more than three similar experiments performed on different cultures. Statistical significance was assessed by analysis of variance and Student-Newman-Keuls test.

Reagents. Stock solutions of the applied drugs were made at least $100 \mathrm{X}$ concentrated in Minimal Essential Medium or distilled water, except cyclothiazide, which was dissolved in DMSO $(10 \mathrm{~mm})$. RS-AMPA and NBQX were provided by Parke-Davis Laboratories (Ann Arbor, MI), and cyclothiazide was provided by Eli Lilly Research Laboratories (Indianapolis, IN). Most other drugs and reagents were purchased from Sigma.

\section{RESULTS}

\section{Characterization of cortical glial cultures}

Dissociated cultures prepared from postnatal mouse neocortex consisted mostly of thin, polygonal cells (see Figs. 2-4). The culture surface was confluent by 2 weeks in vitro. As previously notcd (Choi et al., 1987), a vast majority of thesc cclls $(>95 \%)$ were labeled with antibodies to GFAP. These flat cells were not labeled with antibodies to A2B5, galactocerebroside (gal-C), or MAP-2, which recognize type 2 astrocytes/O-2A progenitor cells, oligodendrocytes, and neurons, respectively (data not shown). The pattern of immunocytochemical labeling is consistent with the designation of these glial cells as type 1-like astrocytes (Raff et al., 1983).

\section{AMPA and kainate receptor currents in cultured astrocytes}

Whole-cell currents gated by glutamate agonists were examined in type 1 astrocytes. Because maintenance of adequate voltageclamp in monolayer astrocyte cultures was difficult because of electrotonic coupling between cells, monolayer cultures were dissociated by addition of trypsin and EGTA and replated at low 
Figure 1. Cyclothiazide enhances AMPA- and kainate-activated wholecell currents in astrocytes. $A-C$ are representative whole-cell recordings from one cortical astrocyte voltage-clamped at $-60 \mathrm{mV}$. A, AMPA or kainate (300 $\mu \mathrm{M})$ applied alone for $300 \mathrm{msec}$ produced small, barely detectable inward currents (the $A M P A$ current exhibits desensitization; see insets). $B, C y$ clothiazide $(C Y Z)(100 \mu \mathrm{M})$ markedly potentiated both AMPA and kainate currents. $C$, AMPA and kainate currents were blocked by $10 \mu \mathrm{M} \mathrm{NBQX}$. Calibration bars are the same for $A-C$. $D$, A different cortical astrocyte stepped to holding potentials between - 90 and $+90 \mathrm{mV}$ at $20 \mathrm{mV}$ increments. At each holding potential, $300 \mu \mathrm{M}$ kainate was applied in the presence of $100 \mu \mathrm{M} c \mathrm{c}$ clothiazide for $300 \mathrm{msec}$. The steadystate current was averaged between the two arrows and plotted versus the holding potential. Kainate alone produced small currents (data not shown), and the $I / \mathrm{V}$ relationship exhibited reversal near $0 \mathrm{mV}$ with strong outward rectification (circles). In $100 \mu \mathrm{M}$ cyclothiazide, the current amplitudes were larger, but the reversal potential remained near 0 $\mathrm{mV}$ and the outward rectification was reduced (squares).

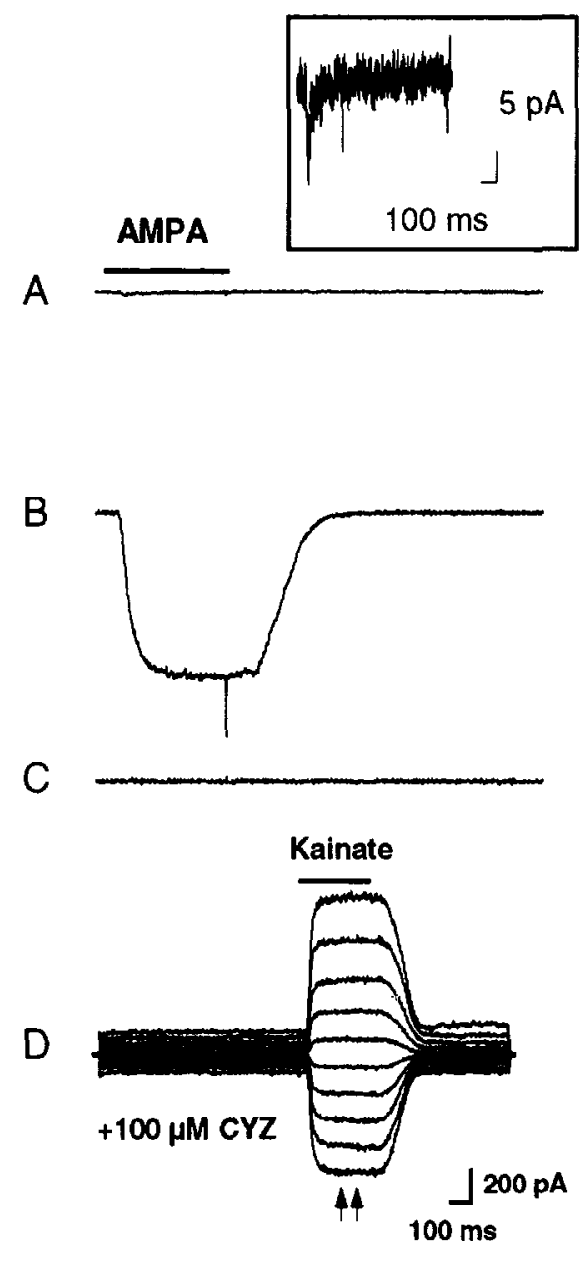

density so that whole-cell recordings could be performed on individual cells. Recordings were obtained from 24 cells. $\Lambda$ MPA $\pm 100 \mu \mathrm{M}$ cyclothiazide was applied to 18 cells. When detectable currents were observed, they exhibited a transient peak response and a smaller steady-state component indicative of rapid desensitization, similar to what is recorded from cortical neurons. The steady-state current was markedly enhanced by cyclothiazide in every cell in which a detectable current was observed $(n=8)$ and in four cells in which no detectable current was observed. The range of enhancement was 5.1-284 times the control steady-state current (this wide range was largely attributable to the difficulty of accurately assessing the very small control steady-state currents). Six of 18 cells did not respond to AMPA even in the presence of cyclothiazide. Kainate \pm cyclothiazide was applied to 14 cells; in 10 of 14 cells kainate produced sustained currents, which were potentiated by cyclothiazide to 1.8-19.8 times the control steadystate current. In 4 of 14 cells there was no response to kainate even with cyclothiazide. In 7 of 24 cells, both AMPA and kainate \pm cyclothiazide, were applied; there were no cells in which one agonist produced a current when the other did not.

Figure $1 A-C$ shows a representative example of a cell in which both AMPA and kainate produced barely detectable currents, which were markedly potentiated by cyclothiazide and blocked by further addition of 2,3-dioxo-6-nitro-7-sulfamoylbenzo( $f$ )quinoxaline (NBQX), a selective compelitive AMPA/ kainate antagonist. When the external solution was changed to one containing no added magnesium and $20 \mu \mathrm{M}$ glycine, $300 \mu \mathrm{M}$ NMDA failed to activate a detectable current, and voltage steps from -60 to $0 \mathrm{mV}$ failed to activate rapid inward sodium currents (data not shown). These latter observations indicate that type 1 astrocytes do not possess NMDA receptors or high threshold, rapidly inactivating voltage-gated sodium conductances. In a few cells the current-voltage (I/V) relationship for AMPA/kainate-activated currents was examined. Without cyclothiazide, the $\mathrm{I} / \mathrm{V}$ relationship was roughly linear, exhibiting outward rectification and a reversal potential near $0 \mathrm{mV}$, although the currents were usually small. In cyclothiazide, the slope-conductance was increased, but the reversal potential remained near $0 \mathrm{mV}$ and outward rectification was reduced (Fig. $1 D$ ). These changes in the I/V relationship are similar to those observed in native neuronal AMPA/kainate receptors with cyclothiazide (Yamada and Tang, 1993).

Ionic currents observed in the present study were attributable to specific activation of ionotropic non-NMDA glutamate receptors rather than to glutamate uptake; they were induced by the selective agonists AMPA or kainate and were blocked by the competitive non-NMDA antagonist NBQX. Because desensitization occurred within milliseconds of AMPA application, it probably would not be observed without rapid drug perfusion and electrical isolation of astrocytes. It is likely that kainate currents also partially desensitized but that this occurred too rapidly to be detected with whole-cell recording. Cyclothiazide increased peak inward currents in response to both AMPA and kainate, revealing responses even in cells for which no current was recorded after application of AMPA alone. Perhaps more significantly, the cyclothiazide-enhanced currents were sustained for the duration of 

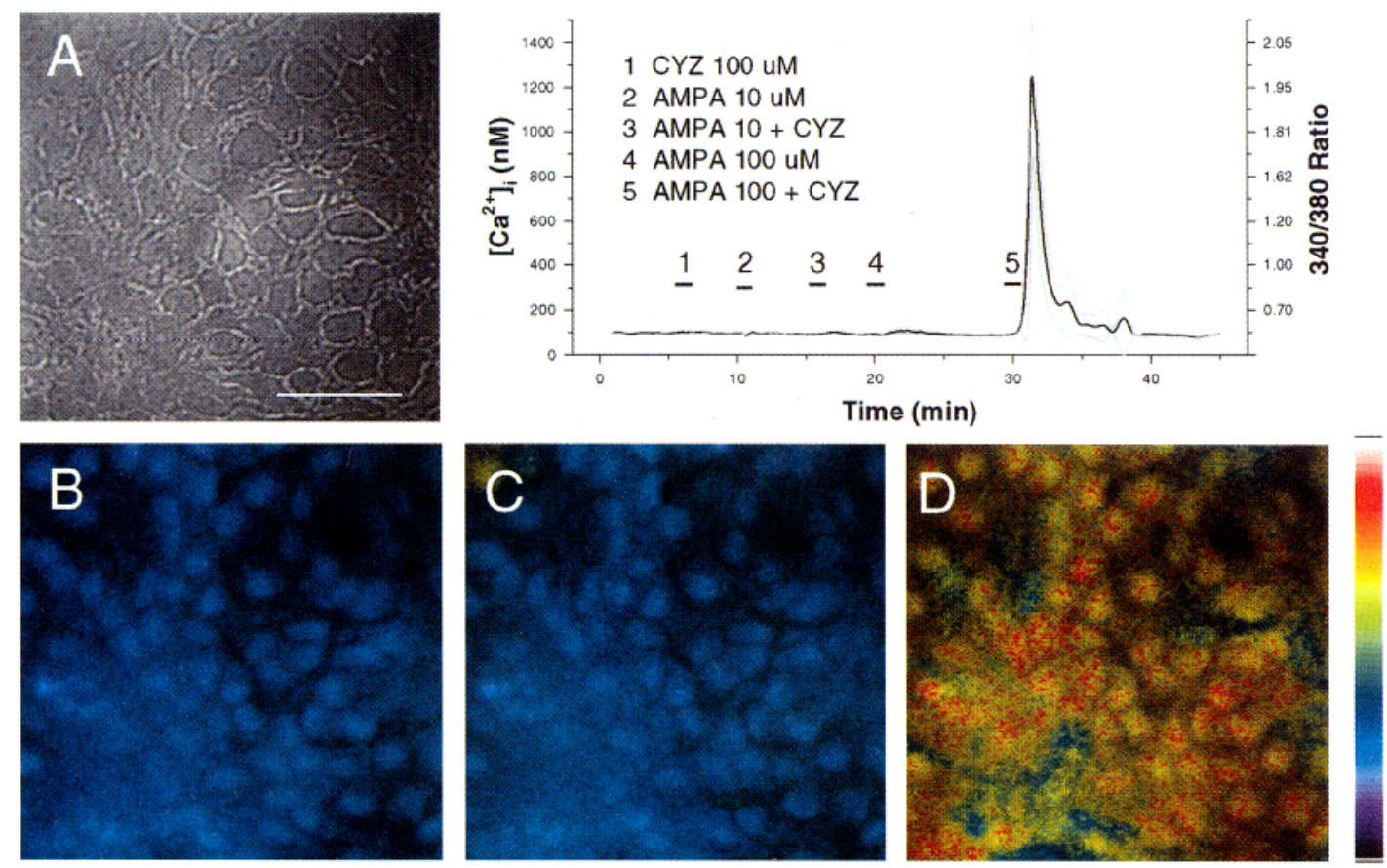

Figure 2. Combined AMPA and cyclothiazide exposure elevates astrocyte $\left[\mathrm{Ca}^{2+}\right]_{\mathrm{i}}$. Type 1 cortical astrocyte cultures were loaded with the fluorescent calcium indicator Fura-2/AM, and $\left[\mathrm{Ca}^{2+}\right]_{i}$ was measured using fluorescence ratio videomicroscopy. The graph shows $340 / 380 \mathrm{~nm}$ excitation ratios obtained during application of $100 \mu \mathrm{M}$ cyclothiazide $(C Y Z)$ or 10-100 $\mu \mathrm{M}$ AMPA as indicated. Lines represent mean (solid) \pm SD (shaded) values for 25 regions of interest in this field, with measurements taken at 10-40 sec intervals. The first panel (top) shows phase-contrast videomicrograph before agonist exposure. The next three panels show fluorescence ratio measurements at peak responses after 1 min application of $100 \mu \mathrm{M}$ cyclothiazide alone $(B), 100$ $\mu \mathrm{M}$ AMPA alone $(C)$, and $100 \mu \mathrm{M}$ AMPA and $100 \mu \mathrm{M}$ cyclothiazide $(D)$. Pseudocolor images are shown using an intensity-modulated display (Tsien and Harootunian, 1990), in which the hues represent the $340 / 380$ ratio (red $=$ high calcium), and the brightness is proportional to the average brightness of the 340 and $380 \mathrm{~nm}$ images. Scale bar, $100 \mu \mathrm{m}$.

agonist application, resulting in a substantial amplification of the steady-state current.

\section{$\left[\mathrm{Ca}^{2+}\right]_{\mathrm{i}}$}

Using Fura-2 fluorescence ratio imaging, resting $\left[\mathrm{Ca}^{2+}\right]_{\mathrm{i}}$ was low $(\sim 50-100 \mathrm{nM})$ and increased minimally in most astrocytes after transient application of 1-300 $\mu \mathrm{M}$ AMPA (Fig. 2). Application of cyclothiazide alone $(100 \mu \mathrm{M})$ did not result in $\left[\mathrm{Ca}^{2+}\right]_{\mathrm{i}}$ elevation. However, application of $100 \mu \mathrm{M}$ AMPA together with $100 \mu \mathrm{M}$ cyclothiazide resulted in a large increase in $\left[\mathrm{Ca}^{2+}\right]_{\mathrm{i}}$ (Fig. 2). In the presence of $100 \mu \mathrm{M}$ cyclothiazide, the effect of AMPA was concentration-dependent, with little $\left[\mathrm{Ca}^{2+}\right]_{\mathrm{i}}$ elevation at $10 \mu \mathrm{M}$ and near-maximal peak responses at 100-300 $\mu \mathrm{M}$. Similar enhancement of $\left[\mathrm{Ca}^{2+}\right]_{i}$ elevation occurred when cyclothiazide was administered with $100-500 \mu \mathrm{M}$ glutamate or kainate (data not shown).

\section{Effect of cyclothiazide on toxicity of glutamate agonists}

We next examined the vulnerability to glutamate agonist application of cortical type 1 astrocytes maintained in primary culture for 1-3 weeks. Continuous exposure of the astrocyte monolayers to wash conditions or to glutamate, NMDA, or AMPA (up to 500 $\mu \mathrm{M})$ resulted in no apparent change in phase-contrast appearance after $24 \mathrm{hr}$ (Fig. $3 A-D$ ) or $48 \mathrm{hr}$ (not shown). In contrast, exposure to $500 \mu \mathrm{M}$ or $1 \mathrm{~mm}$ kainate resulted in a gradual degeneration of astrocytes (Fig. 3E,F). This change was associated with loss of viability of a proportion of cells (typically less than half), as assessed by propidium iodide nuclear fluorescence.

We considered the possibility that the lack of toxicity of glutamate or AMPA, compared with kainate, would reflect the ob- served rapid complete desensitization after AMPA application. To test this hypothesis, we added cyclothiazide during exposures to the glutamate receptor agonists. In the added presence of 100 $\mu \mathrm{M}$ cyclothiazide, AMPA $(500 \mu \mathrm{M})$, kainate $(1 \mathrm{~mm})$, and glutamate $(500 \mu \mathrm{M})$ were rapidly toxic to the cultured astrocytes. This toxicity was apparent within 1-2 hr under phase-contrast optics (Fig. $4 A-C$ ) as a loss of distinct cell boundaries and the appearance of darkened borders surrounding the nuclei. In the subsequent hours, astrocytic nuclei became pyknotic, the cytosol acquired a granular appearance, and many cells detached from the cell surface. The detached cells and most of the remaining cells were not viable, as assessed by a failure to exclude the vital dyes trypan blue or propidium iodide (Fig. $4 D$ ).

The morphological appearance of cell death was accompanied by release of LDH into the bathing medium. Because $1-2 \mathrm{hr}$ exposure to the calcium ionophore ionomycin $(10 \mu \mathrm{M})$ resulted in the death of all cultured glia, this measurement was used as a comparison for all LDH measurements. A small amount of LDH was present in cultures exposed only to wash conditions; this was not significantly increased by $24 \mathrm{hr}$ exposures to $500 \mu \mathrm{M}$ AMPA alone (Fig. 4E). Twenty-four hour exposures to $1 \mathrm{~mm}$ kainate alone did result in significant increases in LDH release (Fig. $4 E$ ). However, extracellular LDH began to accumulate only after $8 \mathrm{hr}$ of continuous kainate exposure. In the presence of $100 \mu \mathrm{M}$ cyclothiazide, both $500 \mu \mathrm{M}$ AMPA and $1 \mathrm{~mm}$ kainate resulted in substantial LDH release within the first $2 \mathrm{hr}$ (Fig. 4E). Most cells could be injured even by transient, $1 \mathrm{hr}$ exposure to $500 \mu \mathrm{M}$ AMPA or $1 \mathrm{~mm}$ kainate together with $100 \mu \mathrm{M}$ cyclothiazide, followed by $24 \mathrm{hr}$ incubation in drug-free medium. The addition 

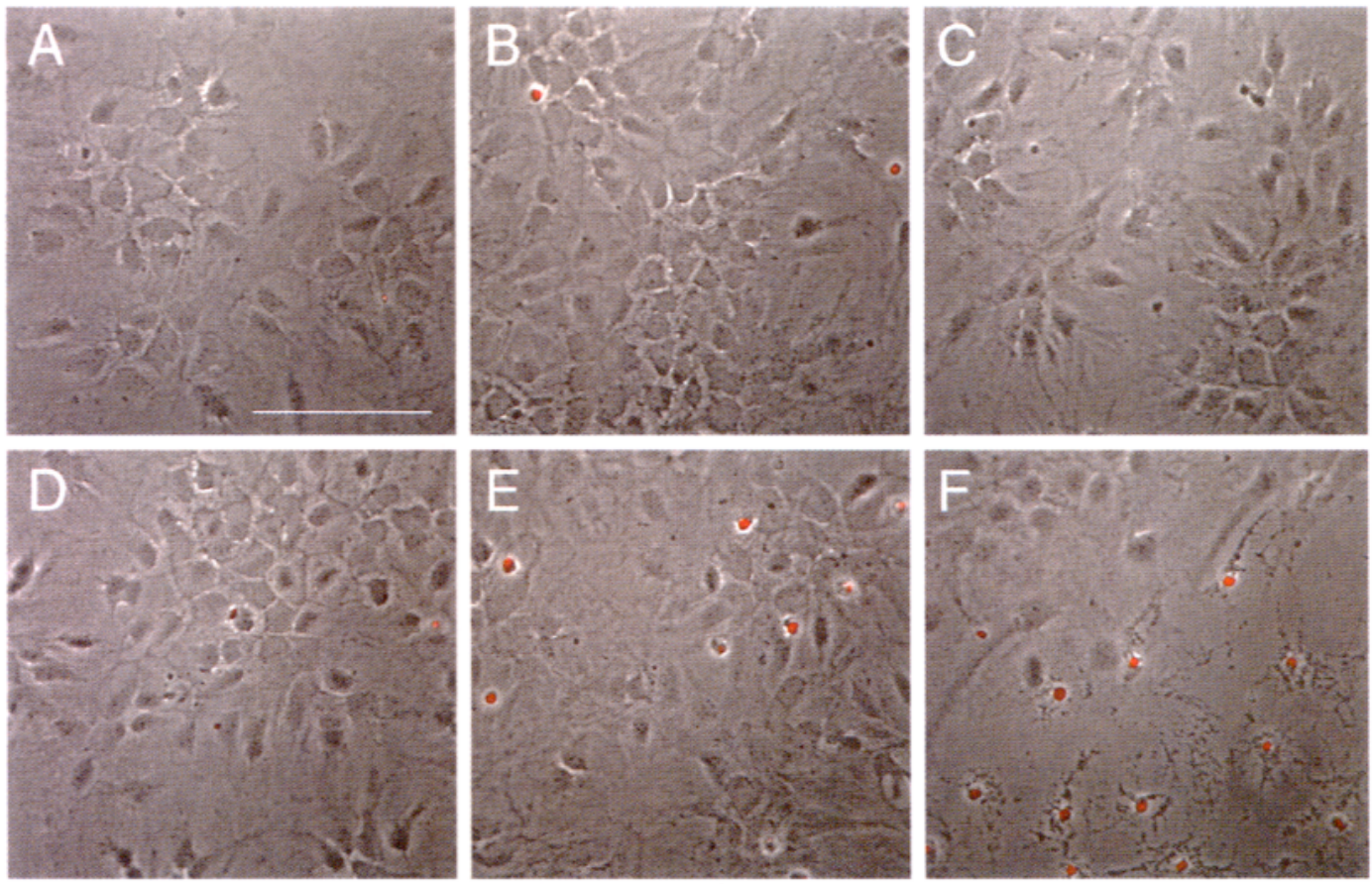

Figure 3. Excitatory amino acid toxicity in cultured cortical astrocytes. Sister cultures of primary astrocyte cultures were exposed to wash $(A)$, $500 \mu \mathrm{M}$ glutamate $(B), 500 \mu \mathrm{M}$ NMDA $(C), 500 \mu \mathrm{M}$ AMPA $(D), 500 \mu \mathrm{M}$ kainate $(E)$, or 1 mM kainate $(F)$ for 24 hr. Panels show phase-contrast videomicrographs (gray) superimposed with propidium iodide fluorescence staining (red) to indicate nonviable cells. Astrocyte death was observed only with prolonged exposures to kainate. Scale bar, $100 \mu \mathrm{m}$.

of NMDA did not cause an increase in LDH release in the presence or absence of cyclothiazide (Fig. 5).

The plant lectin concanavalin A (Con A) enhances currents of kainate-preferring glutamate receptors but not of AMPA receptors (Mayer and Vyklicky, 1989; Huettner, 1990). Experiments with this agent were limited because $24 \mathrm{hr}$ exposure to Con A $(1-5 \mu \mathrm{M})$ caused the astrocytes to separate from the monolayer and to take on a rounded phase-bright appearance. However, exposure to $3 \mu \mathrm{M}$ Con A alone did not result in a loss of viability, as assessed by LDH release or vital dye staining. Because it has been reported that Con A and glucose can compete for lectin-binding sites (Goldstein et al., 1965), we performed these experiments in both low $(0.5 \mathrm{~mm}$, Fig. 6) and normal glucose concentrations ( $5 \mathrm{~mm}$, data not shown) with similar results. In contrast to cyclothiazide, Con A did not significantly potentiate glial toxicity produced by $500 \mu \mathrm{M}$ AMPA (Fig. 6). Con A increased the toxicity of $1 \mathrm{~mm}$ kainate but to a lesser extent than cyclothiazide, and the addition of 30 $\mu \mathrm{M}$ NBQX significantly attenuated kainate toxicity enhanced by Con A (Fig. 6). This result supports the idea that cyclothiazide potentiation of AMPA toxicity is mediated by AMPA-preferring glutamate receptors. However, given the small enhancement of kainate-induced injury by Con A, we cannot exclude the possibility that kainate receptors also mediate toxicity.

The toxicity of $24 \mathrm{hr}$ exposures to glutamate, AMPA, or kainate in the presence of cyclothiazide was dependent on agonist concentrations in the micromolar range (Fig. $7 B-C$ ) and could be attenuated by addition of $30 \mu \mathrm{M}$ NBQX (Fig. 5). The $\mathrm{EC}_{50}$ for each of the agonists with $100 \mu \mathrm{M}$ cyclothiazide was $\sim 30-100 \mu \mathrm{M}$. The cyclothiazide potentiation of AMPA neurotoxicity was concentration-dependent in the 10-100 $\mu \mathrm{M}$ range (Fig. $7 A$ ). Even in the presence of saturating concentrations of both cyclothiazide and glutamate agonists, cell death and corresponding LDH release did not become maximal, indicating that some glial cells were resistant to this insult even though they could be killed by ionomycin.

The results described above were from cultures used within 1-3 weeks from the day of plating (see Materials and Methods). The toxicity of cyclothiazide with glutamate receptor agonists varied with the age of the astrocyte cultures. The response to $100 \mu \mathrm{M}$ cyclothiazide with either $500 \mu \mathrm{M}$ AMPA or $1 \mathrm{~mm}$ kainate was maximal in cultures at $\sim 2$ weeks in vitro but became negligible in most cultures 4 weeks or older (Fig. 8). It remains to be determined whether the observed developmental changes reflect alterations in glutamate receptor expression or in astrocyte resistance to receptor-mediated insults.

\section{DISCUSSION}

Astrocytes in vivo (Martin et al., 1993; Matute et al., 1994) and in vitro (Condorelli et al., 1993) express AMPA/kainate receptor subunit proteins, and glutamate depolarizes astrocytes in primary culture (Bowman and Kimelberg, 1984; Kettenmann et al., 1984) and hippocampal slices (Walz and MacVicar, 1988). However, the characterization of astrocytic AMPA and kainate receptors is incomplete, and the functional significance of glutamate receptor expression in glial cells is largely undefined. Glial cell type and cell type of origin influence the expression of AMPA/kainate receptors (Barres, 1991). Glia can be divided according to a morphological and antigenic classification first proposed for the rat optic nerve (Raff, 1989). Type 1 astrocytes develop from their own precursor cells, whereas type 2 astrocytes and oligodendrocytes develop from common precursors known as O-2A progenitor cells (Raff et al., 1983). NonNMDA glutamate receptor-linked ion channels have been characterized extensively in glial cells of the O2-A lineage both in vitro (Gallo et al., 1989, 1994; Usowicz et al., 1989; Barres et 

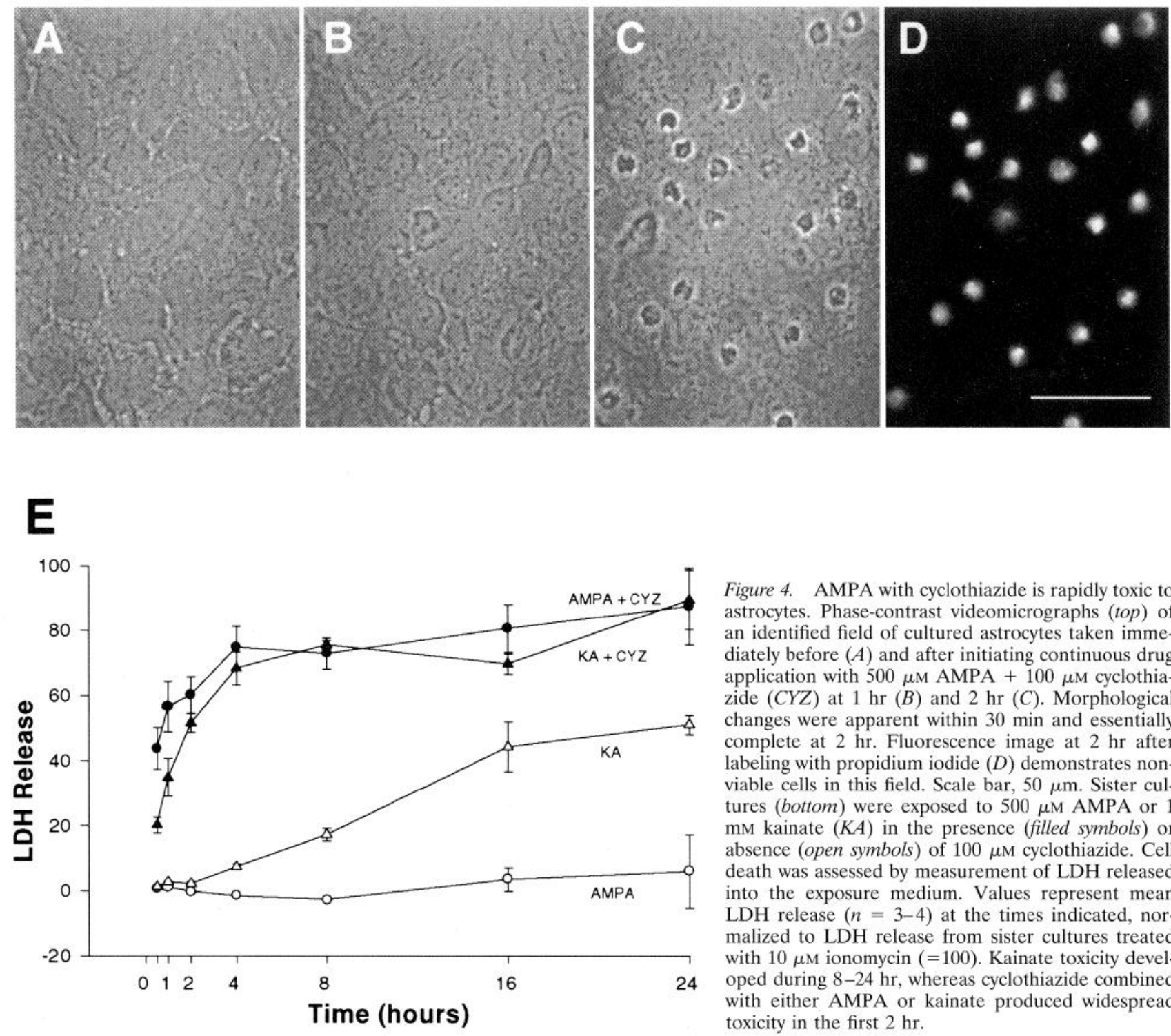

Figure 4. AMPA with cyclothiazide is rapidly toxic to astrocytes. Phase-contrast videomicrographs (top) of an identified field of cultured astrocytes taken immediately before $(A)$ and after initiating continuous drug application with $500 \mu \mathrm{M}$ AMPA $+100 \mu \mathrm{M}$ cyclothiazide $(C Y Z)$ at $1 \mathrm{hr}(B)$ and $2 \mathrm{hr}(C)$. Morphological changes were apparent within $30 \mathrm{~min}$ and essentially complete at $2 \mathrm{hr}$. Fluorescence image at $2 \mathrm{hr}$ after labeling with propidium iodide $(D)$ demonstrates nonviable cells in this field. Scale bar, $50 \mu \mathrm{m}$. Sister cultures (bottom) were exposed to $500 \mu \mathrm{M}$ AMPA or 1 mM kainate $(K A)$ in the presence (filled symbols) or absence (open symbols) of $100 \mu \mathrm{M}$ cyclothiazide. Cell death was assessed by measurement of LDH released into the exposure medium. Values represent mean LDH release $(n=3-4)$ at the times indicated, normalized to LDH release from sister cultures treated with $10 \mu \mathrm{M}$ ionomycin $(=100)$. Kainate toxicity developed during 8-24 hr, whereas cyclothiazide combined with either AMPA or kainate produced widespread toxicity in the first $2 \mathrm{hr}$.

al., 1990a,b; Wyllie et al., 1991; Patneau et al., 1994) and in vivo (Barres et al., 1990a,b; Berger et al., 1992). In contrast, nonNMDA glutamate receptor-mediated responses are observed less consistently in type 1 astrocytes. Depolarizing responses have been shown in some cases to be mediated by electrogenic glutamate uptake (Barbour et al., 1988; Wyllie et al., 1991; Stephens et al., 1993), and several investigators have observed small or absent responses to selective non-NMDA receptor stimulation in type 1 astrocytes (Backus et al., 1989; Barres et al., 1990a). However, other studies using selective agonists support the presence of glutamate receptor-linked ion channels (Sontheimer et al., 1988; Enkvist et al., 1989; Backus et al., 1989; Stephens et al., 1993).

Glia from murine neocortex were identified as type 1-like astrocytes by phase-contrast appearance and antigenic profile. In agreement with other investigators (Backus et al., 1989; Barres et al., 1990a), we found that application of AMPA or kainate alone induced small $(<50 \mathrm{pA})$ or undetectable inward currents. Although such small responses are consistent with a paucity of functional receptors expressed by these cells, our data suggest an additional explanation: the presence of AMPA-induced electro- physiological responses was masked by rapid receptor desensitization. In approximately two-thirds of astrocytes, cyclothiazide, a blocker of AMPA receptor desensitization, produced marked enhancement of AMPA- or kainate-induced currents.

Cultured astrocytes respond to glutamate with an elevation in $\left[\mathrm{Ca}^{2+}\right]_{\mathrm{i}}$ (Glaum et al., 1990; Jensen and Chiu, 1990; Cornell-Bell et al., 1992; Holzwarth et al., 1994; Porter and McCarthy, 1995). In agreement with Jensen and Chiu (1991), application of AMPA or kainate alone on type 1 astrocytes evoked minimal or no increases in $\left[\mathrm{Ca}^{2+}\right]_{\mathrm{i}}$, even when these agonists were applied at high concentrations $(500 \mu \mathrm{M})$. Cyclothiazide alone did not alter astrocyte $\left[\mathrm{Ca}^{2+}\right]_{\mathrm{i}}$, but greatly enhanced $\left[\mathrm{Ca}^{2+}\right]_{\mathrm{i}}$ elevation produced by AMPA, kainate, or glutamate. Although $\mathrm{Ca}^{2+}$-permeable AMPA receptors (Iino et al., 1990) have been described in Bergmann glia (Burnashev et al., 1992; Muller et al., 1992) and in some cells of the O-2A lineage (Fulton et al., 1992; Holzwarth et al., 1994), cyclothiazideenhanced $\left[\mathrm{Ca}^{2+}\right]_{\mathrm{i}}$ elevation in the present experiments probably was not mediated by $\mathrm{Ca}^{2+}$-permeable AMPA receptors. The observed singly rectifying $\mathrm{I} / \mathrm{V}$ relationship in type 1 astrocytes (Fig. $1 D$ ) suggests that GluRB (GluR2) is one of the subunits comprising the channels responsible for these ionic currents and predict that these 


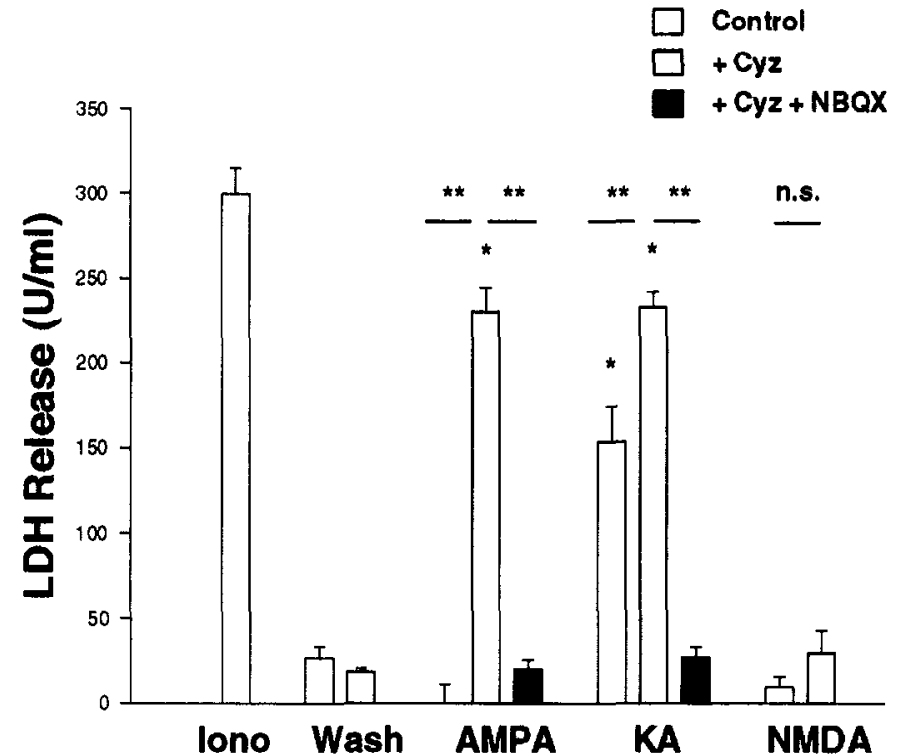

Figure 5. NBQX blocks cyclothiazide-potentiated AMPA or kainate toxicity. Cultures were exposed to the indicated agonists for $24 \mathrm{hr}$ alone (open bar), with $100 \mu \mathrm{M}$ cyclothiazide $(\mathrm{Cyz})$ (shaded bar), or with $100 \mu \mathrm{M}$ cyclothiazide and $30 \mu \mathrm{M} \mathrm{NBQX} \mathrm{(closed} \mathrm{bar).} \mathrm{Conditions} \mathrm{include} \mathrm{wash}$ control (Wash), $500 \mu \mathrm{M}$ AMP $\Lambda, 1 \mathrm{~mm}$ kainate $(K A)$, and $500 \mu \mathrm{M}$ NMDA. Cell death was assessed at the end of exposure by measurement of LDH released into the exposure medium. Exposure to $10 \mu \mathrm{M}$ ionomycin (Iono) was included to indicate maximal $\mathrm{LDH}$ release. Values represent mean $\mathrm{LDH}(\mathrm{U} / \mathrm{ml})+\mathrm{SEM}(n=3-4)$. Asterisks indicate significant difference $(p$ $<0.05)$ from wash control by Student-Newman-Keuls test. Double asterisks indicate significant difference $(p<0.05)$ in the paired conditions, shown with a horizontal bar, by Student-Newman-Keuls test.

channels have low $\mathrm{Ca}^{2+}$ permeability (Hollmann et al., 1991). Cyclothiazide did not result in AMPA-induced $\left[\mathrm{Ca}^{2+}\right]_{i}$ elevation in the absence of extracellular sodium (our unpublished data), suggesting that intracellular $\mathrm{Ca}^{2+}$ accumulation occurred only by indirect path-

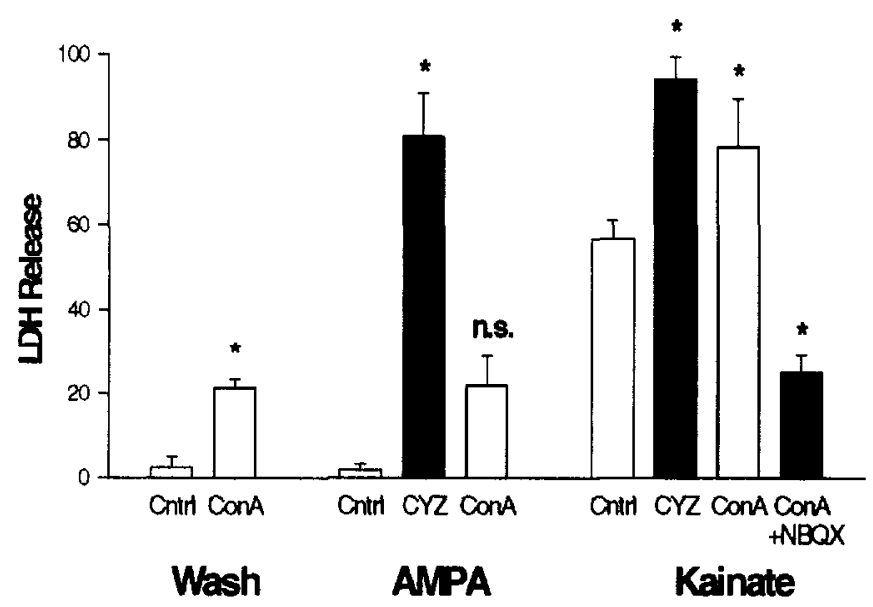

Figure 6. Con A enhances kainate but not AMPA toxicity. Cultures were exposed for $24 \mathrm{hr}$ to wash conditions (Wash), $500 \mu \mathrm{M}$ AMPA, or $1 \mathrm{~mm}$ kainate, either alone or in the presence of $100 \mu \mathrm{M}$ cyclothiazide $(C Y Z), 3$ $\mu \mathrm{M}$ Con A, or $3 \mu \mathrm{M}$ Con A $+30 \mu \mathrm{M}$ NBQX. Values represent mean LDH release $(n=3-4)$, normalized to $L D H$ release from sister cultures treated with $10 \mu \mathrm{M}$ ionomycin $(=100)$. Asterisks indicate significant difference $(p<$ 0.05 ) from wash controls by Student-Newman-Keuls test. All experiments were performed in medium containing $0.5 \mathrm{~mm}$ glucose to reduce possible competition for Con A action (see text).

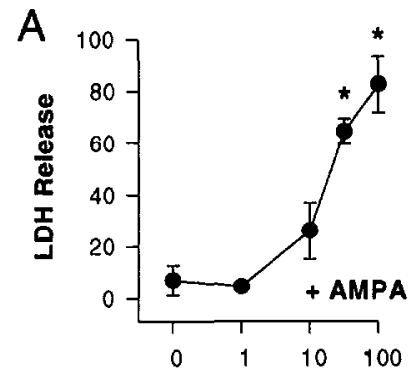

[Cyclothiazide] $(\mu \mathrm{M})$

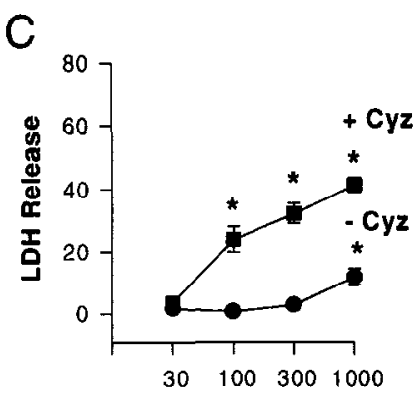

[Kainate] $(\mu \mathrm{M})$

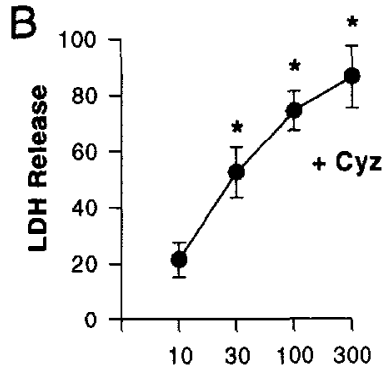

[AMPA] $(\mu \mathrm{M})$

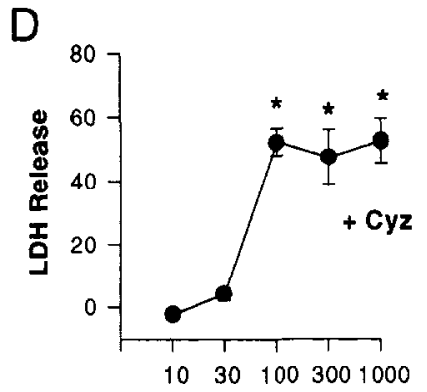

[Glutamate] $(\mu \mathrm{M})$
Figure 7. Concentration dependence of cyclothiazide and glutamate receptor agonist effects. $A$, Cyclothiazide concentration-response curve. Cultures were exposed for $24 \mathrm{hr}$ to $500 \mu \mathrm{M}$ AMPA with the indicated concentrations of cyclothiazide. Asterisks indicate significant difference $(p$ $<0.05$ ) from AMPA alone by Student-Newman-Keuls test. $B-D$, Agonist concentration-response curves. Cultures were exposed for $24 \mathrm{hr}$ to the indicated agonists ( $B, A M P A ; C$, kainate; $D$, glutamate) with or without 100 $\mu \mathrm{M}$ cyclothiazide. Values represent mean LDH release $(n=4)$ normalized to $\mathrm{LDH}$ release from sister cultures treated with $10 \mu \mathrm{M}$ ionomycin $(=100)$. Asterisks indicate significant difference $(p<0.05)$ from wash control by Student-Newman-Keuls test.

ways, potentially including reversed operation of the $\mathrm{Na}^{+} / \mathrm{Ca}^{2+}$ exchanger.

Brief exposures to glutamate or to glutamate agonists alone are sufficient to destroy CNS neurons in many culture systems. However, although selective activation of glutamate receptors induces a number of morphological and biochemical alterations in astrocytes (Koh et al., 1990; Noble et al., 1992; Sun et al., 1992), such treatments do not lead to astrocyte cell death (Rothman, 1984; Choi et al., 1987; Koh et al., 1990; Bridges et al., 1992). Glutamate-mediated toxicity has been observed in a few forms of glial injury. Haas and Erdo (1991) reported that astrocytes maintained in serum-free conditions could be injured by $24 \mathrm{hr}$ exposures to quisqualate but not kainate, leading these authors to propose a role for metabotropic receptormediated injury. Oka et al. (1993) found that cultured oligodendrocytes were susceptible to prolonged glutamate exposure. This toxicity was not reproduced by selective agonists and seemed to involve glutamate uptake rather than receptor activation. In contrast, glial injury in the present experiments was associated with overactivation of ionotropic glutamate receptors. Prolonged exposure to $500 \mu \mathrm{M}$ concentrations of glutamate, AMPA, and NMDA produced no injury. Although exposure to kainate caused astrocyte death, this toxicity was submaximal and occurred only when kainate was applied at very high concentrations $(500 \mu \mathrm{M}$ or $1 \mathrm{mM})$ for durations of 


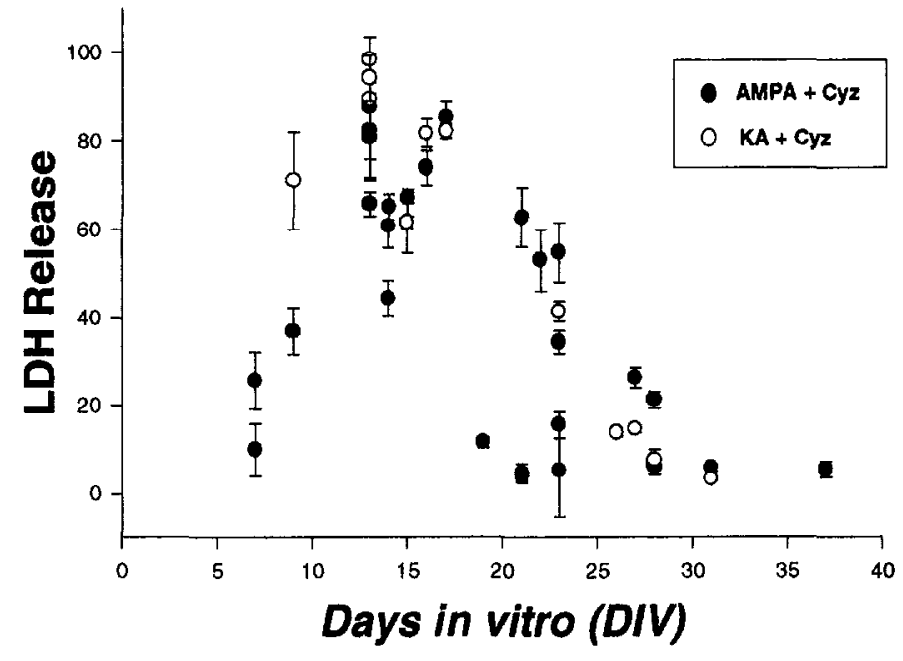

Figure 8. Cyclothiazide enhancement of injury depends on the age of astrocyte cultures. Cyclothiazide $(C y z)(100 \mu \mathrm{M})$ potentiation of $500 \mu \mathrm{M}$ AMPA (filled circles) or $1 \mathrm{mM}$ kainate $(K A)$ (open circles) toxicity was examined in 38 sets of cultures at the indicated day in vitro. Values represent mean $\mathrm{LDH} \pm \mathrm{SEM}$ obtained from three to four sister cultures at each point, normalized to LDH release present in matched sister cultures after exposure to $10 \mu \mathrm{M}$ ionomycin. Maximal sensitivity to AMPA or kainate with cyclothiazide occurred during the second and third week in vitro, with diminished toxicity in most cultures older than 3 weeks.

many hours (16-24 hr). In the presence of cyclothiazide, otherwise sublethal concentrations of glutamate, AMPA, and kainate became highly toxic, producing extensive astrocyte degeneration within the first few hours of application. This dramatic effect was concentration-dependent for each of the agonists $\left(\mathrm{EC}_{50} 30-100 \mu \mathrm{M}\right)$ and was abolished by the further addition of NBQX. These observations indicate that glial excitotoxic injury was mediated by overactivation of AMPA receptors. The ionic mechanisms of this injury remain to be established. AMPA receptor activation in the presence of cyclothiazide was associated with sustained elevation of intracellular $\mathrm{Ca}^{2+}$. As is true of neuronal excitotoxicity, both $\mathrm{Ca}^{2+}$. dependent and $\mathrm{Ca}^{2+}$-independent mechanisms may potentially contribute to glial injury.

Several observations suggest that astrocyte glutamate receptors are dominated by AMPA-type subunits. In agreement with the observed results in astrocytes, AMPA-preferring nonNMDA glutamate receptors in central neurons are characterized by complete desensitization in the presence of glutamate or AMPA but only partial desensitization in the presence of kainate (see Zorumski and Thio, 1992). The glial toxicity of kainate at high concentrations (without added cyclothiazide) but not of AMPA or glutamate may be attributable to the small but sustained currents evoked by kainate in these cells. In the present experiments, AMPA toxicity was enhanced by cyclothiazide but not by the lectin Con A. Cyclothiazide has been shown to selectively enhance responses of AMPA- but not kainate-preferring glutamate receptor subunits in isolated expression systems, whereas Con A is relatively selective for enhancement of kainate receptors (Partin et al., 1993; Patneau et al., 1994). These types of responses to AMPA and kainate, including their potentiation by cyclothiazide, suggest that astrocyte glutamate receptors resemble native neuronal AMPA receptors. However, the state of AMPA receptor desensitiza- tion may play a more significant role in astrocytes than in neurons. In neurons, AMPA by itself induces readily measurable inward currents, $\left[\mathrm{Ca}^{2+}\right]_{i}$ elevation, and slow toxicity, whereas these are all absent in astrocytes unless cyclothiazide is present. In the presence of cyclothiazide, AMPA-induced glial currents and $\left[\mathrm{Ca}^{2+}\right]_{\mathrm{i}}$ elevation were of almost the same magnitude (nA range) as those from cultured neurons under the same conditions (Yamada and Tang, 1993; Moudy et al., 1994).

Relatively little is known about desensitization of astrocyte AMPA receptors in vivo. Cultured astrocytes are known to differ from their in vivo counterparts in many respects (Barres et al, 1990a), and it is possible that cortical astrocytes are more susceptible to excitotoxic insults in vivo. For example, although isolated astrocytes are substantially less vulnerable than neurons to combincd oxygen-glucosc deprivation in cortical cultures (Callahan ct al., 1990; Goldberg and Choi, 1993), both glia and neurons can be destroyed during cerebral infarction after focal ischemia. McDonald et al. (1992) observed that cortical and striatal injury (involving necrosis of all cell types) after intracerebral injection of AMPA was maximal at postnatal day 10 and subsequently declined during development. We are intrigued by the parallel time course of astrocyte vulnerability to AMPA-mediated cell death in culture (Fig. 8) (see also Oka et al., 1993). In addition to direct effects leading to cell death, astrocyte AMPA receptor stimulation may participate in injury indirectly by altering glial-glial (Dani et al., 1992; Jensen and Chiu, 1990; Cornell-Bell et al., 1992) or glial-neuronal (Mennerick and Zorumski, 1994; Nedergaard, 1994; Parpura et al., 1994) interactions. AMPA exposure triggers glutamate release from cortical astrocytes (Dugan et al., 1995), and this is greatly enhanced by the addition of cyclothiazide (David et al., 1995b). Blockade of astrocyte AMPA receptors may contribute to the protective actions of AMPA antagonists in animal models of cerebral ischemia (Sheardown et al., 1990).

Primary cell cultures allow examination of effects of glial AMPA receptors in isolation trom effects on neurons. The cell culture model of cyclothiazide-enhanced glutamate toxicity may provide novel opportunities to study mechanisms of astrocyte vulnerability to excitotoxic insults. These observations raise the possibility that astrocyte injury during acute brain insults such as stroke or trauma is limited by the extent of AMPA receptor desensitization, and they suggest that pharmacological approaches to enhancing AMPA receptor desensitization will have therapeutic value.

\section{REFERENCES}

Backus KH, Kettenmann H, Schachner M (1989) Pharmacological characterization of the glutamate receptor in cultured astrocytes. J Neurosci Res 22:274-282.

Barbour B, Brew H, Attwell D (1988) Electrogenic glutamate uptake in glial cells is activated by intracellular potassium. Nature 335:433-435.

Barres BA (1991) Glial ion channels. Curr Opin Neurobiol 1:354-359.

Barres BA, Koroshetz WJ, Chun LL, Corey DP (1990a) Ion channel expression by white matter glia: the type-1 astrocyte. Neuron 5:527-544

Barres BA, Koroshetz WJ, Swartz KJ, Chun LLY, Corey DP (1990b) Ion channel expression by white matter glia: the O-2A glial progenitor cell Neuron 4:507-524.

Bateman MC, Bagwe MR, Yamada KA, Goldberg MP (1993) Cyclothiazide potentiates AMPA neurotoxicity and oxygen-glucose deprivation injury in cortical culture. Soc Neurosci Abstr 19:1643.

Berger T, Walz W, Schnitzer J, Kettenmann H (1992) GABA- and glutamate-activated currents in glial cells of the mouse corpus callosum slice. J Neurosci Res 31:21-27. 
Bowman CL, Kimelberg HK (1984) Excitatory amino acids directly depolarize rat brain astrocytes in primary culture. Nature 311:656-659.

Bridges RJ, Hatalski CG, Shim SN, Cummings BJ, Vijayan V, Kundi A, Cotman CW (1992) Gliotoxic actions of excitatory amino acids. Neuropharmacology 31:899-907.

Burnashev N, Khodorova A, Jonas P, Helm PJ, Wisden W, Monyer H, Seeburg PH, Sakmann B (1992) Calcium-permeable AMPA/kainate receptors in fusiform cerebellar glial cells. Science 256:1566-1570.

Callahan DJ, Engle MJ, Volpe JJ (1990) Hypoxic injury to developing glial cells: protective effect of high glucose. Pediatr Res 27:186-190.

Choi DW (1992) Excitotoxic cell death. J Neurobiol 23:1261-1276.

Choi DW, Maulucci Gedde MA, Kriegstein AR (1987) Glutamate neuroluxicily in cortical cell culture. J Neurosci 7:357-368.

Condorelli DF, Dell'Albani P, Corsaro M, Barresi V, Giuffrida Stella AM (1993) AMPA-selective glutamate receptor subunits in astroglial cultures. J Neurosci Res 36:344-356.

Cornell-Bell AH, Finkbeiner SM, Cooper MS, Smith SJ (1992) Glutamate induces calcium waves in cultured astrocytes: long-range glial signaling. Science $247: 470-473$.

Dani JW, Chernjavsky A, Smith SJ (1992) Neuronal activity triggers calcium waves in hippocampal astrocyte networks. Neuron 8:429-440.

David JC, Rosengarten AM, Yamada KA, Goldberg MP (1995a) Receptor desensitization limits AMPA-induced calcium accumulation and cell injury in cultured astrocytes. Neurology [Suppl 4] 45:A309.

David JC, Yamada KA, Dugan LL, Gabrielsen JKJ, Rosengarten AM, Goldberg MP (1995b) AMPA receptor desensitization masks rapid glutamate excitotoxicity in cultured mouse cortical astrocytes. Soc Neurosci Abstr 21:1340

Dugan LL, Bruno VMG, Amagasu SM, Giffard RG (1995) Glia modulate the response of murine cortical neurons to excitotoxicity: glia exacerbate AMPA neurotoxicily. J Neurusci 15:4545-4555.

Enkvist MO, Holopainen I, Akerman KE (1989) Glutamate receptorlinked changes in membrane potential and intracellular $\mathrm{Ca}^{2+}$ in primary rat astrocytes. Glia 12:397-402.

Fulton BP, Burne JF, Raff MC (1992) Visualization of O-2A progenitor cells in developing and adult rat optic nerve by quisqualate-stimulated cobalt uptake. J Neurosci 12:4816-4833.

Gallo V, Giovannini C, Suergiu R, Levi G (1989) Expression of excitatory amino acid receptors by cerebellar cells of the type- 2 astrocyte cell lineage. J Neurochem 52:1-9.

Gallo V, Patneau DK, Mayer ML, Vaccarino FM (1994) Excitatory amino acid receptors in glial progenitor cells: molecular and functional properties. Glia 11:94-101.

Glaum SR, Holzwarth JA, Miller RJ (1990) Glutamate receptors activate $\mathrm{Ca}^{2+}$ mobilization and $\mathrm{Ca}^{2+}$ influx into astrocytes. Proc Natl Acad Sci USA 87:3454-3458

Goldberg MP, Choi DW (1993) Oxygen-glucose deprivation cortical culture: calcium-dependent and calcium-independent mechanisms of neuronal injury. J Neurosci 13:3510-3524.

Goldstcin IJ, Hollcrman CE, Smith EE (1965) Protcin-carbohydratc interaction. II. Inhibition studies on the interaction of concanavalin with polysaccharides. Biochemistry 4:876-883.

Grynkiewicz G, Poenie M, Tsien RY (1985) A new generation of $\mathrm{Ca}^{2+}$ indicators with greatly improved fluorescence properties. J Biol Chem 260:3440-3450.

Haas J, Erdo SL (1991) Quisqualate-induced excitotoxic death of glial cells: transient vulnerability of cultured astrocytes. Glia 4:111-114.

Hamill OP, Marty A, Neher E, Sakmann B, Sigworth FJ (1981) Improved patch-clamp techniques for high-resolution current recording from cells and cell-free membrane patches. Pflügers Arch 391:85-100.

Hollmann M, Hartley M, Heinemann S (1991) $\mathrm{Ca}^{2+}$ permeability of KA-AMPA-gated glutamate receptor channels depends on subunit composition. Science 252:851-853.

Holzwarth JA, Gibbons SJ, Brorson JR, Philipson LH, Miller RJ (1994) Glutamate receptor agonists stimulate diverse calcium responses in different types of cultured rat cortical glial cells. J Neurosci 14:1879-1891

Hosli E, Hosli L. (1993) Receptors for neurotransmitters on astrocytes in the mammalian central nervous system. Prog Neurobiol 40:477-506.

Huettner JE (1990) Glutamate receptor channels in rat DRG neurons: activation by kainate and quisqualate and blockade of desensitization by Con A. Neuron 5:255-266. lino M, Ozawa S, Tsuzuki K (1990) Permeation of calcium through excitatory amino acid receptor channels in cultured rat hippocampal neurones. J Physiol (Lond) 424:151-165

Jensen AM, Chiu SY (1990) Fluorescence measurement of changes in intracellular calcium induced by excitatory amino acids in cultured cortical astrocytes. J Neurosci 10:1165-1175.

Jensen AM, Chiu SY (1991) Differential intracellular calcium responses to glutamate in type 1 and type 2 cultured brain astrocytes. J Neurosci 11:1674-1684.

Kettenmann H, Backus KH, Schachner M (1984) Aspartate, glutamate and gamma-aminobutyric acid depolarize cultured astrocytes. Neurosci Lett 52:25-29.

Kettenmann H, Schachner M (1985) Pharmacological properties of $\gamma$-aminobutyric acid-, glutamate-, and aspartate-induced depolarizations in cultured astrocytes. J Neurosci 5:3295-3301.

Koh J, Goldberg MP, Hartley DM, Choi DW (1990) Non-NMDA receptor-mediated neurotoxicity in cortical culture. J Neurosci 10:693-705.

Koh JY, Choi DW (1987) Quantitative determination of glutamate mediated cortical neuronal injury in cell culture by lactate dehydrogenase efflux assay. J Neurosci Methods 20:83-90.

Martin LJ, Blackstone CD, Levey AI, Huganir RL, Price DL (1993) AMPA glutamate receptor subunits are differentially distributed in rat brain. Neuroscience 53:327-358.

Matute C, Gutierrez-Igarza K, Kio C, Miledi R (1994) Glutamate receptors in astrocytic end-feet. NeuroReport 5:1205-1208.

May PC, Robison PM (1993) Cyclothiazide treatment unmasks AMPA excitotoxicity in rat primary hippocampal cultures. J Neurochem 60:1171-1174.

Mayer ML, Vyklicky LJ (1989) Concanavalin A selectively reduces desensitization of mammalian neuronal quisqualate receptors. Proc Natl Acad Sci USA 86:1411-1415.

McDonald JW, Trescher WH, Johnston MV (1992) Susceptibility of brain to AMPA induced excitotoxicity transiently peaks during early postnatal development. Brain Res 583:54-70.

Mennerick S, Zorumski CF (1994) Glial contributions to excitatory neurotransmission in cultured hippocampal cells. Nature 368:59-62.

Moudy AM, Yamada KA, Rothman SM (1994) Rapid desensitization determines the pharmacology of glutamate neurotoxicity, Neuropharmacology 33:953-962.

Muller T, Moller T, Berger T, Schnitzer J, Kettenmann H (1992) Calcium entry through kainate receptors and resulting potassium-channel blockade in Bergmann glial cells. Science 256:1563-1566.

Nedergaard M (1994) Direct signaling from astrocytes to neurons in cultures of mammalian brain cells. Science 263:1768-1771.

Noble LJ, Hall JJ, Chen S, Chan PH (1992) Morphologic changes in cultured astrocytes after exposure to glutamate. J Neurotrauma 9:255-267.

Oka A, Belliveau MJ, Rosenberg PA, Volpe JJ (1993) Vulnerability of oligodendroglia to glutamate: pharmacology, mechanisms, and prevention. J Neurosci 13:1441-1453.

Parpura V, Basarsky TA, Liu F, Jeftinija K, Jeftinija S, Haydon PG (1994) Glutamate-mediatcd astrocyte-neuron signalling. Nature 369:744-747.

Partin KM, Patneau DK, Winters CA, Mayer ML, Buonanno A (1993) Selective modulation of desensitization at AMPA versus kainate receptors by cyclothiazide and concanavalin A. Neuron 11:1069-1082.

Patneau DK, Vyklicky L Jr, Mayer ML (1993) Hippocampal neurons exhibit cyclothiazide-sensitive rapidly desensitizing responses to kainate. J Neurosci 13:3496-3509.

Patneau DK, Wright PW, Winters C, Mayer ML, Gallo V (1994) Glial cells of the oligodendrocyte lineage express both kainate-and AMPApreferring subtypes of glutamate receptor. Neuron 12:357-371.

Porter JT, McCarthy KD (1995) GFAP-positive hippocampal astrocytes in situ respond to glutamatergic neuroligands with increases in $\left[\mathrm{Ca}^{2+}\right]_{i}$. Glia 13:101-112.

Probert AW, Marcoux FW (1993) Cyclothiazide potentiation of oxygen and glucose deprivation-induced ${ }^{45} \mathrm{Ca}^{2+}$ uptake and $\mathrm{LDH}$ release in cerebrocortical cell culture. Soc Neurosci Abstr 19:1341.

Raff MC (1989) Glial cell diversification in the rat optic nerve. Science 243:1450-1455.

Raff MC, Abney ER, Cohen J, Lindsay R, Noble M (1983) Two types of astrocytes in cultures of developing rat white matter: differences in morphology, surface gangliosides, and growth characteristics. J Neurosci 3:1289-1300.

Ruse K, Goldbery MP, Choi DW (1993) Cytotoxicity in murine cortical cell culture. In: In vitro biological methods. Methods in 
toxicology (Tyson CA, Frazier JM, eds), pp 46-60. San Diego: Academic.

Rothman S (1984) Synaptic release of excitatory amino acid neurotransmitter mediates anoxic neuronal death. J Neurosci 4:1884-1891.

Sheardown MJ, Nielsen EO, Hansen AJ, Jacobsen P, Honore T (1990) 2,3-Dihydroxy-6-nitro-7-sulfamoyl-benzo $(F)$ quinoxaline: a neuroprotectant for cerebral ischemia. Science 247:571-574.

Sontheimer H, Kettenmann H, Backus KH, Schachner M (1988) Glutamate opens $\mathrm{Na}^{+} / \mathrm{K}^{+}$channels in cultured astrocytes. Glia 1:328-336.

Stephens GJ, Djamgoz MB, Wilkin GP (1993) A patch clamp study of excitatory amino acid effects on cortical astrocyte subtypes in culture. Receptors Channels 1:39-52.

Sun AY, Cheng Y, Sun GY (1992) Kainic acid-induced excitotoxicity in neurons and glial cells. Prog Brain Res 94:271-280.

Tsien RY, Harootunian AT (1990) Practical design criteria for a dynamic ratio imaging systcm. Coll Calcium 11:93-109.

Usowicz MM, Gallo V, Cull Candy SG (1989) Multiple conductance channels in type- 2 cerebellar astrocytes activated by excitatory amino acids. Nature 339:380-383.
Walz W, MacVicar B (1988) Electrophysiological properties of glial cells: comparison of brain slices with primary cultures. Brain Res 443:321-324.

Wong LA, Mayer ML (1993) Differential modulation by cyclothiazide and concanavalin $\mathrm{A}$ of desensitization at native alpha-amino-3-hydroxy-5-methyl-4-isoxazolepropionic acid- and kainate-preferring glutamate receptors. Mol Pharmacol 44:504-510.

Wyllie DJ, Mathie A, Symonds CJ, Cull-Candy SG (1991) Activation of glutamate receptors and glutamate uptake in identified macroglial cells in rat cerebellar cultures. J Physiol (Lond) 432:235-258.

Yamada KA, Tang CM (1993) Benzothiadiazides inhibit rapid glutamate receptor desensitization and enhance glutamatergic synaptic currents. J Neurosci 13:3904-3915.

Zorumski CF, Thio LL (1992) Properties of vertebrate glutamate receptors: calcium mobilization and desensitization. Prog Neurobiol 39:295-336.

Zorumski CF, Thio LL, Clark GD, Clifford DB (1990) Blockade of desensitization augments quisqualate excitotoxicity in hippocampal neurons. Neuron 5:61-66. 